\title{
KAJIAN DESAIN STRUKTUR BENDUNG DAN KOLAM OLAKAN DARI BAHAYA REMBESAN (SEEPAGE)
}

\author{
Oleh: \\ ANWAR \\ Dosen Teknik Sipil Universitas Sang Bumi Ruwa Jurai
}

\begin{abstract}
ABSTRAK
Bendung selain digunakan sebagai peninggi elevasi muka air, juga dapat digunakan sebagai alat ukur debit air. Bendung dan bendungan masing-masing memiliki fungsi yang berbeda. Bendung dibuat sebagai peninggi elevasi muka air sehingga dengan kondisi permukaan air yang telah dibendung air akan dialirkan ke tempat yang diinginkan. Sedangkan bendungan digunakan untuk menampung aliran, bila terjadi over flow diharapkan tidak terjadi banjir besar yang diakibatkan terlalu tingginya elevasi permukaan air yang mengalir pada saluran tersebut, atau dengan kata lain fungsi daripada bendungan tersebut sebagai pengendali banjir. Salah satu masalah yang sering terjadi pada bendung adalah adanya rembesan pada tubuh bendungan tersebut. Rembesan terjadi apabila bangunan harus mengatasi beda tinggi muka air dan jika aliran yang disebabkannya meresap masuk ke dalam tanah di sekitar bangunan. Kerusakan bendungan di lokasi penelitian diakibatkan banjir dan seepage. Hasil perhitungan curah hujan maksimum rancangan kala ulang 50 tahunan untuk stasiun Basohan adalah 294,097 mm. Hasil perhitungan debit maksimum banjir rancangan dengan berbagai metode adalah sebesar $341,243 \mathrm{~m}^{3} / \mathrm{dtk}$ dengan metode HSS Snyder. Berdasarkan data debit rancangan yang ada diperoleh ketinggian mercu yang dibutuhkan yaitu tipe bulat dengan elevasi 91,3076 m di hulu dan 90,2958 di hilir bendung. Hasil perhitungan panjang coveran untuk mengurangi energi rembesan yaitu sepanjang $3 \mathrm{~m}$. Hasil perhitungan rembesan di dasar tubuh bendung diperoleh sepanjang 29,47 m. Dengan demikian panjang konstruksi dasar bendungan minimal harus sepanjang 29,47 m. Untuk meredam aliran pada saat keluar, maka didesain kolam olakan sepanjang $6 \mathrm{~m}$ dengan tebal lantai olak sebesar $0,8 \mathrm{~m}$.
\end{abstract}

Kata kunci : bending, over flow, banjir, konstruksi, aliran.

\section{PENDAHULUAN}

Tanah merupakan kumpulan butirbutiran mineral alam yang melekat tetapi tidak erat, sehingga masih mudah dipisah-pisahkan. Tanah yang lokasinya pindah dari tempat terjadinya akibat aliran air, angin, dan es disebut transported soil. Tanah yang tidak pindah lokasinya dari tempat terjadinya disebut residual soil. Tanah yang bersifat rembesan kecil dan daya rembes besar disebabkan ukuran pori-pori dan butiranbutiran tanah yang kecil, sedangkan tanah yang bersifat rembesan besar dan daya rembes kecil disebabkan ukuran pori-pori dan butiran tanah yang besar (Bowles, 1989).

Bendung selain digunakan sebagai peninggi elevasi muka air, juga dapat digunakan sebagai alat ukur debit air. Bendung dan bendungan masing-masing memiliki fungsi yang berbeda. Bendung 
dibuat sebagai peninggi elevasi muka air sehingga dengan kondisi permukaan air yang telah dibendung air akan dialirkan ke tempat yang kita inginkan. Sedangkan bendungan digunakan untuk menampung aliran, bila terjadi over flow diharapkan tidak terjadi banjir besar yang diakibatkan terlalu tingginya elevasi permukaan air yang mengalir pada saluran tersebut, atau dengan kata lain fungsi daripada bendungan tersebut sebagai pengendali banjir.

Salah satu masalah yang sering terjadi pada bendung adalah adanya rembesan pada tubuh bendungan tersebut. Rembesan terjadi apabila bangunan harus mengatasi beda tinggi muka air dan jika aliran yang disebabkannya meresap masuk ke dalam tanah di sekitar bangunan. Aliran ini mempunyai pengaruh yang dapat merusak stabilitas bangunan karena terangkutnya bahanbahan halus sehingga dapat menyebabkan erosi bawah tanah (piping). Jika erosi bawah tanah sudah terjadi, maka terbentuklah lajur rembesan (jaringan aliran) antara bagian hulu dan hilir bangunan. Air rembesan yang mengalir pada lapisan tanah akan mengangkut butiran tanah yang lebih halus menuju lapisan tanah yang kasar. Erosi butiran mengakibatkan turunnya tahanan aliran air dan naiknya gradien hidrolis. Bila kecepatan aliran membesar akibat dari pengurangan tahanan aliran yang berangsur-angsur turun, akan terjadi erosi butiran yang lebih besar lagi, sehingga membentuk pipa-pipa di dalam tanah yang dapat mengakibatkan keruntuhan pada tubuh bendung. Oleh karena itu diperlukan suatu penelitian untuk menganalisis pola aliran rembesan pada bendung.

\section{METODOLOGI}

Penelitian Kajian Desain Struktur Bendung ini dilakukan di Bendung Way Basohan Kabupaten Lampung Barat.

Sumber data yang akan digunakan dalam penyusunan penelitian ini adalah pengumpulan data melalui observasi data sekunder. Sumber data yang diperoleh penulis dalam penelitian ini berasal dari Balai Besar Wilayah Sungai Mesuji Sekampung yang terdiri dari data desain bangunan bendung, dan data tinggi muka air di bendung. 


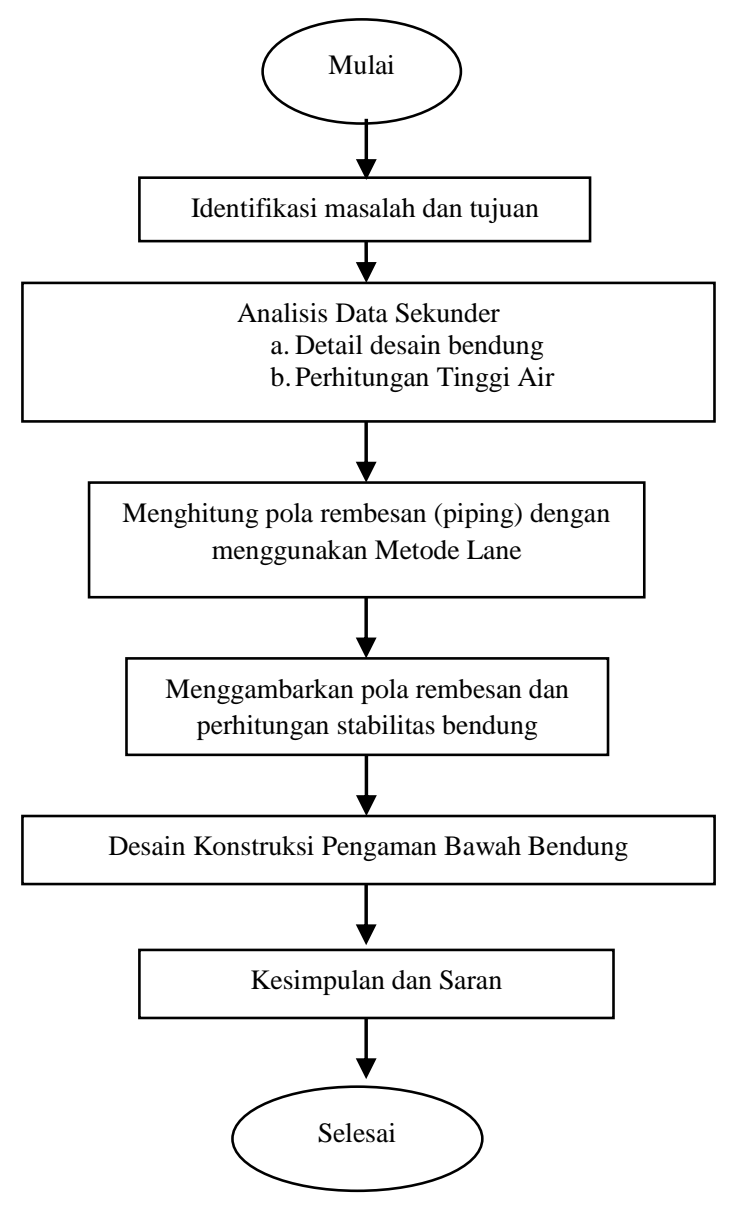

Gambar 1. Bagan Alir Penelitian

\section{HASIL DAN PEMBAHASAN}

\section{Kondisi Kelengkapan Bangunan \\ Utama Bendung Way Basohan}

Kondisi bangunan dan kelengkapan Bangunan Utama Bendung Way Basohan dari hasil investigasi awal dapat dijelaskan secara ringkas sebagai berikut:

Tubuh bendung, dengan mercu berbentuk bulat dengan kemiringan bidang hilir $1: 1$ dan sebelah hulu tegak, kondisi tubuh bendung yang dulunya ada setengah bangunan (tegak) sekarang sudah hancur semuanya.

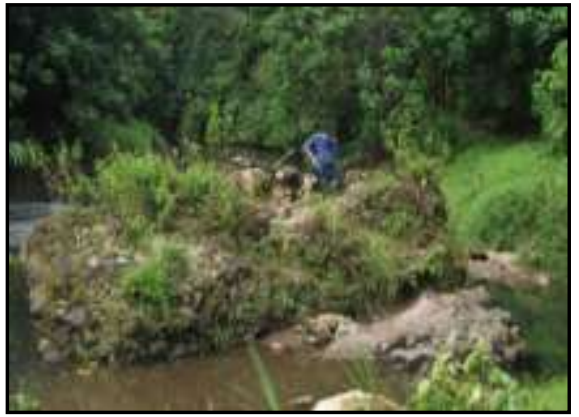

Gambar 2 Kondisi Tubuh Bendung yang Telah Rusak Berat
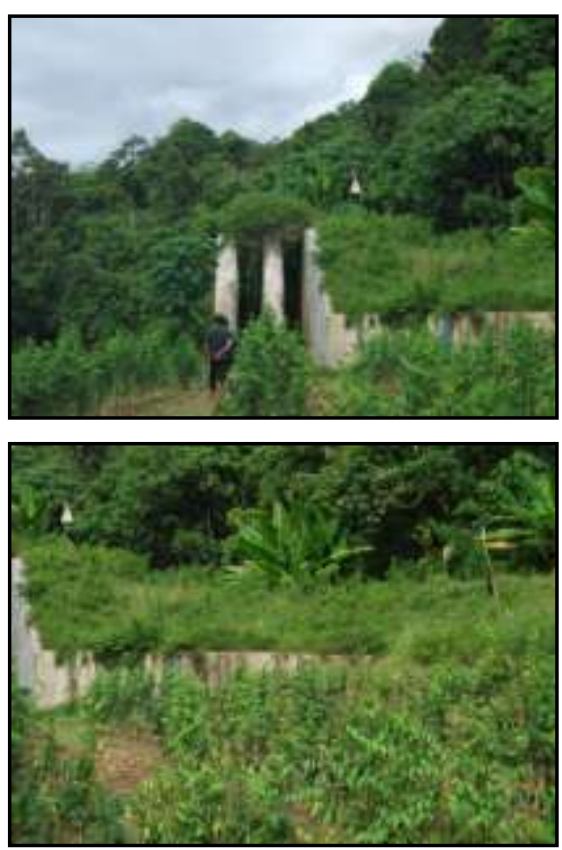

Gambar 3 Kondisi Bangunan Pembilas dan Sayap Hilir Bendung Way Basohan yang Sudah Tertutupi Rumput Liar

Tembok pangkal bendung, berupa pasangan batu kali dengan kondisi tembok pangkal bendung pada sebelah kiri sudah mengalami keretakan pada beberapa titik.

Tembok sayap udik, berupa pasangan batu kali yang disatukan dengan tembok pangkal tanggul yang menempel langsung pada tebing sungai, hanya ada 
pada bagian kiri. Masih dapat dikatakan dalam kondisi mungkin untuk dipertahankan, walaupun pada pangkalnya terjadi kerusakan.

Tembok sayap hilir, dari pasangan batu kali merupakan tembok perkuatan tebing, dengan kedalaman koperan tembok kaki $2.50 \mathrm{~m}$ dari elevasi dasar coupure, alinyemen disatukan dengan tembok sayap udik Bottom Controller, masih dapat dikatakan baik walaupun perlu penambahan perkuatan jika dipertahankan.

\section{Bangunan Intake Kiri dan Lantai}

Pembilas, elevasi ambang intake $=\mathrm{EL}+$ 48.570, tinggi skimming wall $=1.00 \mathrm{~m}$, lebar pintu intake $=2 \times 0.6 \mathrm{~m}$ dengan pilar 1 x $0.80 \mathrm{~m}$, lahan yang dialiri sekitar 260 Ha. Lantai pembilas berada di bawah intake (undersluice) dengan elevasi + 43.036, kondisi saat ini telah pecah-pecah pada bangunan pintu intake dan di belakang pintu tanah telah amblas akibat proses kelongsoran.

\section{Analisis Data Curah Hujan Maksimum}

Pada dasarnya, penentuan data curah hujan harian maksimum satu stasiun per tahun dipilih dan dibandingkan dengan curah hujan pada hari yang sama pada stasiun lain. Curah hujan harian maksimum yang didapat masih merupakan hujan titik (point rainfall), sehingga perlu dihitung curah hujan DAS (area rainfall). Untuk menghitung curah hujan DAS besaran ini dapat ditempuh dengan beberapa metode yang sampai saat ini lazim digunakan, yaitu dengan rata-rata Aljabar, metode Polygon Thiessen dan Metode Isohyet. Ada lagi satu metode perataan hujan yang terkait dengan metode Hidrograf Satuan yakni dengan menghitung koefisien reduksi B.

Tabel 1 Data Curah Hujan Maksimum

Tahunan Stasiun Basohan

\begin{tabular}{|c|c|c|c|c|}
\hline No & \multicolumn{3}{|c|}{ Tanggal Kejadian } & Curah Hujan (mm) \\
\hline 1 & 2 & April & 2015 & 170.0 \\
\hline 2 & 25 & Desember & 2014 & 288.0 \\
\hline 3 & 13 & Februari & 2013 & 185.0 \\
\hline 4 & 21 & April & 2012 & 182.0 \\
\hline 5 & 6 & Januari & 2011 & 180.0 \\
\hline 6 & 13 & Februari & 2010 & 231.0 \\
\hline 7 & 26 & Januari & 2009 & 74.0 \\
\hline 8 & 31 & Agustus & 2008 & 173.0 \\
\hline 9 & 15 & Desember & 2007 & 115.0 \\
\hline 10 & 16 & Mei & 2006 & 123.0 \\
\hline 11 & 27 & April & 2005 & 195.0 \\
\hline 12 & 25 & Februari & 2004 & 117.0 \\
\hline 13 & 8 & Januari & 2003 & 110.0 \\
\hline 14 & 30 & Juni & 2002 & 145.0 \\
\hline 15 & 6 & Januari & 2001 & 127.0 \\
\hline
\end{tabular}

Sumber : Diolah Dari Data Curah Hujan

Harian (BBWS Mesuji Sekampung)

Jumlah ( $\mathrm{n}=$ banyaknya data) dan interval tahun pengamatan dari masing-masing stasiun pada penelitian ini tidak sama, hal ini dikarenakan waktu mulai pemakaian alat penakar hujan untuk tiap stasiun berbeda dan terjadinya kerusakan alat 
sehingga ada tahun pengamatan yang tidak memiliki data hujan. Dalam proses perhitungan analisis frekuensi, data hujan untuk tiap-tiap durasi nantinya diurutkan dari yang terkecil ke yang besar.

\section{Penentuan Hujan Rancangan}

Tabel 2 Perhitungan Sebaran Distribusi

Data Hidrologi Stasiun Basohan

\begin{tabular}{|c|c|c|c|c|c|}
\hline No & $\mathbf{X i}$ & $\begin{array}{c}\mathbf{X i}- \\
\mathbf{X}_{\text {rerata }}\end{array}$ & $\begin{array}{c}(\mathbf{X i}- \\
\left.\mathbf{X}_{\text {rerata }}\right)^{2}\end{array}$ & $\begin{array}{c}(\mathbf{X i}- \\
\left.\mathbf{X}_{\text {rerata }}\right)^{3}\end{array}$ & $\left(\mathbf{X i}-\mathbf{X}_{\text {rerata }}\right)^{4}$ \\
\hline & $(\mathbf{m m})$ & $(\mathbf{m m})$ & $(\mathrm{mm})^{2}$ & $(\mathrm{~mm})^{3}$ & $(\mathbf{m m})^{4}$ \\
\hline 1 & 74.00 & -87.0000 & 7569.0000 & -658503.00 & 57289761.00 \\
\hline 2 & 110.00 & -51.0000 & 2601.0000 & -132651.00 & 6765201.00 \\
\hline 3 & 115.00 & -46.0000 & 2116.0000 & -97336.00 & 4477456.00 \\
\hline 4 & 117.00 & -44.0000 & 1936.0000 & -85184.00 & 3748096.00 \\
\hline 5 & 123.00 & -38.0000 & 1444.0000 & -54872.00 & 2085136.00 \\
\hline 6 & 127.00 & -34.0000 & 1156.0000 & -39304.00 & 1336336.00 \\
\hline 7 & 145.00 & -16.0000 & 256.0000 & -4096.00 & 65536.00 \\
\hline 8 & 170.00 & 9.0000 & 81.0000 & 729.00 & 6561.00 \\
\hline 9 & 173.00 & 12.0000 & 144.0000 & 1728.00 & 20736.00 \\
\hline 10 & 180.00 & 19.0000 & 361.0000 & 6859.00 & 130321.00 \\
\hline 11 & 182.00 & 21.0000 & 441.0000 & 9261.00 & 194481.00 \\
\hline 12 & 185.00 & 24.0000 & 576.0000 & 13824.00 & 331776.00 \\
\hline 13 & 195.00 & 34.0000 & 1156.0000 & 39304.00 & 1336336.00 \\
\hline 14 & 231.00 & 70.0000 & 4900.0000 & 343000.00 & 24010000.00 \\
\hline 15 & 288.00 & 127.0000 & 16129.0000 & 2048383.00 & 260144641.00 \\
\hline$\sum$ & 2415.0 & 0.0 & 40866.0 & 1391142.0 & 361942374.0 \\
\hline & $\mathrm{X}_{\text {rerata }}=$ & 161.00 & & & \\
\hline & $\mathrm{Sd}=$ & 54.03 & & & \\
\hline & $\mathrm{Ck}=$ & 4.3762 & & & \\
\hline & $\mathrm{Cs}=$ & 0.7270 & $\mathrm{Cs} / \mathrm{Cv}=$ & 2.1665 & \\
\hline & $\mathrm{Cv}=$ & 0.3356 & & & \\
\hline
\end{tabular}

Dari perhitungan di atas, kemudian dilanjutkan dengan pemilihan distribusi yang tepat dengan parameter sebagai berikut :
Tabel 3 Hasil Perhitungan Distribusi

\begin{tabular}{|c|c|c|c|c|}
\hline \multicolumn{5}{|c|}{ Syarat Pemilihan Distribusi ( Sri Harto ) } \\
\hline No & $\begin{array}{c}\text { Distribus } \\
\text { i }\end{array}$ & Syarat & Nilai & $\begin{array}{c}\text { Keteranga } \\
\mathrm{n}\end{array}$ \\
\hline 1 & Normal & $\mathrm{Cs}=0$ & 0.7270 & $\begin{array}{c}\text { Tidak } \\
\text { Memenuhi }\end{array}$ \\
\hline & & $\mathrm{Ck}=$ & 4.3762 & $\begin{array}{c}\text { Tidak } \\
\text { Memenuhi }\end{array}$ \\
\hline 2 & Gumbel & $\begin{array}{l}\text { Cs }= \\
1,1396\end{array}$ & 0.7270 & $\begin{array}{c}\text { Tidak } \\
\text { Memenuhi }\end{array}$ \\
\hline & & $\begin{array}{l}\mathrm{Ck}= \\
5,4002\end{array}$ & 4.3762 & $\begin{array}{c}\text { Tidak } \\
\text { Memenuhi }\end{array}$ \\
\hline 3 & $\begin{array}{c}\log \\
\text { Normal }\end{array}$ & $\begin{array}{l}\mathrm{Cs}=3 \\
\mathrm{Cv}+\mathrm{Cv} 2 \\
=3\end{array}$ & 1.1193 & $\begin{array}{c}\text { Tidak } \\
\text { Memenuhi }\end{array}$ \\
\hline & & $\begin{array}{r}\mathrm{Ck}= \\
5,3833\end{array}$ & 4.3762 & $\begin{array}{c}\text { Tidak } \\
\text { Memenuhi }\end{array}$ \\
\hline 3 & $\begin{array}{c}\text { Log } \\
\text { Pearson }\end{array}$ & Cs $\neq 0$ & 0.7270 & Memenuhi \\
\hline
\end{tabular}

Karena analisis pemilihan jenis distribusi di atas tidak ada yang memenuhi syarat tersebut, maka digunakan distribusi Log Pearson Tipe III. Dengan nilai sifat statistikseperti tersebut di atas, diperoleh sebaran yang paling cocok yaitu distribusi Log-Pearson Tipe III begitu pula dengan durasi yang lainnya. Penggambaran data pada kertas probabilitas dilakukan dengan cara mengurutkan data hujan dari nilai terkecil sampai ke nilai terbesar kemudian diplotkan pada kertas probabilitas, disajikan pada Tabel di bawah ini. 
Tabel 4 Analisis Statistik Data Hidrologi

DAS Basohan dengan Log

Pearson Tipe III

\begin{tabular}{|c|c|c|c|c|c|c|}
\hline $\begin{array}{l}\mathbf{N} \\
\mathbf{o}\end{array}$ & $\begin{array}{c}\mathbf{X i} \\
(\mathbf{m m})\end{array}$ & $\begin{array}{c}\log \\
\mathrm{Xi}\end{array}$ & $\begin{array}{c}\log X_{\mathrm{i}}^{-} \\
\log \mathrm{X}_{\text {rerata }}\end{array}$ & $\begin{array}{c}\text { Log } \\
\mathrm{Xi}- \\
\log \\
\mathrm{X}_{\text {rerata }} \\
)^{2}\end{array}$ & $\begin{array}{c}(\log \mathrm{Xi} \\
-\log \\
\left.\mathrm{X}_{\text {rerata }}\right)^{3}\end{array}$ & $\begin{array}{c}\text { (Log } \\
\text { Xi - } \\
\text { Log } \\
\left.\mathrm{X}_{\text {rerata }}\right) \\
4\end{array}$ \\
\hline 1 & 74.00 & $\begin{array}{c}1.869 \\
2\end{array}$ & -0.31468 & $\begin{array}{c}0.099 \\
02\end{array}$ & $\begin{array}{c}- \\
0.03116\end{array}$ & $\begin{array}{c}0.009 \\
81\end{array}$ \\
\hline 2 & $\begin{array}{c}110.0 \\
0\end{array}$ & $\begin{array}{c}2.041 \\
4\end{array}$ & -0.14252 & $\begin{array}{c}0.020 \\
31\end{array}$ & $\begin{array}{c}- \\
0.00289\end{array}$ & $\begin{array}{c}0.000 \\
41\end{array}$ \\
\hline 3 & $\begin{array}{c}115.0 \\
0\end{array}$ & $\begin{array}{c}2.060 \\
7\end{array}$ & -0.12321 & $\begin{array}{c}0.015 \\
18\end{array}$ & $\begin{array}{c}- \\
0.00187\end{array}$ & $\begin{array}{c}0.000 \\
23\end{array}$ \\
\hline 4 & $\begin{array}{c}117.0 \\
0\end{array}$ & $\begin{array}{c}2.068 \\
2\end{array}$ & -0.11572 & $\begin{array}{c}0.013 \\
39\end{array}$ & $\begin{array}{c}- \\
0.00155\end{array}$ & $\begin{array}{c}0.000 \\
18\end{array}$ \\
\hline 5 & $\begin{array}{c}123.0 \\
0\end{array}$ & $\begin{array}{c}2.089 \\
9\end{array}$ & -0.09400 & $\begin{array}{c}0.008 \\
84\end{array}$ & $\begin{array}{c}- \\
0.00083\end{array}$ & $\begin{array}{c}0.000 \\
08\end{array}$ \\
\hline 6 & $\begin{array}{c}127.0 \\
0\end{array}$ & $\begin{array}{c}2.103 \\
8\end{array}$ & -0.08011 & $\begin{array}{c}0.006 \\
42\end{array}$ & $\begin{array}{c}- \\
0.00051\end{array}$ & $\begin{array}{c}0.000 \\
04\end{array}$ \\
\hline 7 & $\begin{array}{c}145.0 \\
0\end{array}$ & $\begin{array}{c}2.161 \\
4\end{array}$ & -0.02254 & $\begin{array}{c}0.000 \\
51\end{array}$ & $\begin{array}{c}- \\
0.00001\end{array}$ & $\begin{array}{c}0.000 \\
00\end{array}$ \\
\hline 8 & $\begin{array}{c}170.0 \\
0\end{array}$ & $\begin{array}{c}2.230 \\
4\end{array}$ & 0.04654 & $\begin{array}{c}0.002 \\
17\end{array}$ & 0.00010 & $\begin{array}{c}0.000 \\
00\end{array}$ \\
\hline 9 & $\begin{array}{c}173.0 \\
0\end{array}$ & $\begin{array}{c}2.238 \\
0\end{array}$ & 0.05414 & $\begin{array}{c}0.002 \\
93\end{array}$ & 0.00016 & $\begin{array}{c}0.000 \\
01\end{array}$ \\
\hline $\begin{array}{l}1 \\
0\end{array}$ & $\begin{array}{c}180.0 \\
0\end{array}$ & $\begin{array}{c}2.255 \\
3\end{array}$ & 0.07136 & $\begin{array}{c}0.005 \\
09\end{array}$ & 0.00036 & $\begin{array}{c}0.000 \\
03\end{array}$ \\
\hline $\begin{array}{l}1 \\
1\end{array}$ & $\begin{array}{c}182.0 \\
0\end{array}$ & $\begin{array}{c}2.260 \\
1\end{array}$ & 0.07616 & $\begin{array}{c}0.005 \\
80\end{array}$ & 0.00044 & $\begin{array}{c}0.000 \\
03\end{array}$ \\
\hline $\begin{array}{l}1 \\
2\end{array}$ & $\begin{array}{c}185.0 \\
0\end{array}$ & $\begin{array}{c}2.267 \\
2\end{array}$ & 0.08326 & $\begin{array}{c}0.006 \\
93\end{array}$ & 0.00058 & $\begin{array}{c}0.000 \\
05\end{array}$ \\
\hline $\begin{array}{l}1 \\
3\end{array}$ & $\begin{array}{c}195.0 \\
0\end{array}$ & $\begin{array}{c}2.290 \\
0\end{array}$ & 0.10613 & $\begin{array}{c}0.011 \\
26\end{array}$ & 0.00120 & $\begin{array}{c}0.000 \\
13\end{array}$ \\
\hline $\begin{array}{l}1 \\
4\end{array}$ & $\begin{array}{c}231.0 \\
0\end{array}$ & $\begin{array}{c}2.363 \\
6\end{array}$ & 0.17970 & $\begin{array}{c}0.032 \\
29\end{array}$ & 0.00580 & $\begin{array}{c}0.001 \\
04\end{array}$ \\
\hline $\begin{array}{l}1 \\
5\end{array}$ & $\begin{array}{c}288.0 \\
0\end{array}$ & $\begin{array}{c}2.459 \\
4\end{array}$ & 0.27548 & $\begin{array}{c}0.075 \\
89\end{array}$ & 0.02091 & $\begin{array}{c}0.005 \\
76\end{array}$ \\
\hline$\sum$ & $\begin{array}{c}2415 . \\
00\end{array}$ & $\begin{array}{c}32.75 \\
86\end{array}$ & 0.000000 & $\begin{array}{c}0.306 \\
03\end{array}$ & $\begin{array}{c}- \\
0.00927 \\
0\end{array}$ & $\begin{array}{c}0.017 \\
800\end{array}$ \\
\hline & $\begin{array}{r}\log \mathrm{X}_{\mathrm{rer}} \\
\mathrm{Sd}= \\
\mathrm{Cs}=\end{array}$ & $=$ & $\begin{array}{r}32.7586 \\
2.1839 \\
0.1479 \\
-0.2367\end{array}$ & & & \\
\hline
\end{tabular}

\section{Perhitungan Curah Hujan Rancangan}

Curah hujan rancangan didefinisikan sebagai tinggi curah hujan yang secara statistik akan terjadi atau terlampaui satu kali dalam suatu kala ulang tertentu. Untuk memperkirakan besarnya curah hujan dengan kala ulang tertentu digunakan analisis frekuensi sebagai perhitungan atau peramalan suatu peristiwa hujan yang menggunakan data historis dan frekuensi kejadiannya. Hasil perhitungan curah hujan rancangan untuk berbagai kala ulang disajikan dalam tabel di bawah ini.

Tabel 5 Hasil Perhitungan Curah Hujan Rancangan

\begin{tabular}{||c|c|c|c|c|c|c|c||}
\hline $\begin{array}{c}\text { Kala } \\
\text { Ulang }\end{array}$ & $\begin{array}{c}\mathrm{P} \\
(\%)\end{array}$ & Log Xi & $\mathrm{Sd}$ & $\mathrm{K}$ & $\mathrm{K} . \mathrm{Sd}$ & $\mathrm{Log} \mathrm{Xt}$ & $\begin{array}{c}\mathrm{Xt} \\
(\mathrm{mm})\end{array}$ \\
\hline \hline $\mathbf{2}$ & 50 & 2.184 & 0.1479 & 0.0392 & 0.0058 & 2.1897 & $\mathbf{1 5 4 . 7 7 9}$ \\
$\mathbf{5}$ & 20 & 2.184 & 0.1479 & 0.8511 & 0.1258 & 2.3097 & $\mathbf{2 0 4 . 0 5 4}$ \\
$\mathbf{1 0}$ & 10 & 2.184 & 0.1479 & 1.2532 & 0.1853 & 2.3692 & $\mathbf{2 3 3 . 9 9 1}$ \\
$\mathbf{2 5}$ & 4 & 2.184 & 0.1479 & 1.6664 & 0.2464 & 2.4303 & $\mathbf{2 6 9 . 3 3 2}$ \\
$\mathbf{5 0}$ & 2 & 2.184 & 0.1479 & 1.9248 & 0.2846 & 2.4685 & $\mathbf{2 9 4 . 0 9 7}$ \\
$\mathbf{1 0 0}$ & 1 & 2.184 & 0.1479 & 2.1508 & 0.3180 & 2.5019 & $\mathbf{3 1 7 . 6 2 0}$ \\
$\mathbf{5 0 0}$ & 0.2 & 2.184 & 0.1479 & 2.4217 & 0.3581 & 2.5420 & $\mathbf{3 4 8 . 3 0 9}$ \\
$\mathbf{1 0 0 0}$ & 0.1 & 2.184 & 0.1479 & 2.7604 & 0.4081 & 2.5920 & $\mathbf{3 9 0 . 8 7 3}$ \\
& & & & & & \\
\hline
\end{tabular}

Penentuan Besarnya Intensitas Hujan

Untuk keperluan

pengalihragaman data hujan ke besaran debit banjir (hidrograf banjir) dengan metode hidrograf satuan, diperlukan data hujan jam-jaman. Distribusi hujan jamjaman dapat diperoleh dari catatan stasiun hujan otomatis. Di daerah studi maupun di DAS terdekat tidak tersedia data hujan jam-jaman. Oleh sebab itu, hujan jam- 
jaman akan diperkirakan berdasarkan karakteristik hujan secara umum hasil penyelidikan Van Breen di Indonesia, dimana hujan harian terkonsentrasi selama 4 jam dengan jumlah hujan sebesar $90 \%$ dari jumlah hujan selama 24 jam, dengan distribusi 10\%, 40\%, 40\% dan $10 \%$. Dengan anggapan bahwa hujan rancangan untuk berbagai kala ulang memiliki distribusi hujan jam-jaman yang sama seperti tersebut di atas, maka hujan jam-jaman sungai Basohan dapat ditentukan dengan menggunakan metode Mononobe seperti disajikan pada Tabel di bawah ini.

Tabel 4.6 Intensitas Hujan Jam-Jaman dengan Metode Mononobe

DAS Basohan

\begin{tabular}{|c|c|c|c|c|c|c|c|c|}
\hline $\begin{array}{l}\text { Dur } \\
\text { asi }\end{array}$ & \multicolumn{8}{|c|}{ Kala Ulang (tahun) } \\
\hline (me & \multirow[b]{2}{*}{2} & \multirow[b]{2}{*}{5} & \multirow[b]{2}{*}{10} & \multirow[b]{2}{*}{25} & \multirow[b]{2}{*}{50} & \multirow[b]{2}{*}{100} & \multirow[b]{2}{*}{500} & 100 \\
\hline nit) & & & & & & & & 0 \\
\hline & 281. & 370. & 425. & 489. & 534. & 577. & 632. & 710. \\
\hline 5 & 252 & 791 & 190 & 409 & 410 & 154 & 919 & 263 \\
\hline \multirow[b]{2}{*}{10} & 177. & 233. & 267. & 308. & 336. & 363. & 398. & 447. \\
\hline & 178 & 583 & 853 & 308 & 657 & 584 & 714 & 438 \\
\hline \multirow[b]{2}{*}{15} & 135. & 178. & 204. & 235. & 256. & 277. & 304. & 341. \\
\hline & 212 & 258 & 410 & 283 & 917 & 466 & 276 & 459 \\
\hline \multirow[b]{2}{*}{20} & 111. & 147. & 168. & 194. & 212. & 229. & 251. & 281. \\
\hline & 615 & 148 & 737 & 222 & 081 & 044 & 174 & 868 \\
\hline \multirow[b]{2}{*}{45} & 65.0 & 85.6 & 98.2 & 113. & 123. & 133. & 146. & 164. \\
\hline & 03 & 97 & 70 & 112 & 513 & 392 & 281 & 156 \\
\hline \multirow[b]{2}{*}{60} & 53.6 & 70.7 & 81.1 & 93.3 & 101. & 110. & 120. & 135. \\
\hline & 59 & 42 & 20 & 72 & 958 & 113 & 752 & 508 \\
\hline \multirow[b]{2}{*}{120} & 33.8 & 44.5 & 51.1 & 58.8 & 64.2 & 69.3 & 76.0 & 85.3 \\
\hline & 03 & 64 & 02 & 21 & 29 & 67 & 69 & 65 \\
\hline \multirow[b]{2}{*}{180} & 25.7 & 34.0 & 38.9 & 44.8 & 49.0 & 52.9 & 58.0 & 65.1 \\
\hline & 96 & 09 & 98 & 89 & 16 & 37 & 51 & 45 \\
\hline \multirow[b]{2}{*}{240} & 21.2 & 28.0 & 32.1 & 37.0 & 40.4 & 43.6 & 47.9 & 53.7 \\
\hline & 95 & 74 & 93 & 55 & 62 & 98 & 20 & 76 \\
\hline \multirow[b]{2}{*}{300} & 18.3 & 24.1 & 27.7 & 31.9 & 34.8 & 37.6 & 41.2 & 46.3 \\
\hline & 51 & 93 & 43 & 33 & 69 & 58 & 97 & 43 \\
\hline
\end{tabular}

\section{Perhitungan Debit Banjir Rancangan}

\section{Sungai Basohan}

Di dalam perencanaan bangunan pengairan, debit rencana diperlukan untuk mengetahui kapasitas yang seharusnya dapat terjadi, agar semua debit air dapat ditampung dan teralirkan. Salah satu metode yang umum digunakan untuk memperkirakan laju aliran puncak (debit banjir atau debit rencana) yaitu Metode Rasional United States Soil Conservation Service (USSCS). Metode ini diaplikasikan dengan menggunakan parameter:
a. Koefisien Pengaliran (c)
b. Intensitas (I), dan
c. Luas DAS (A)

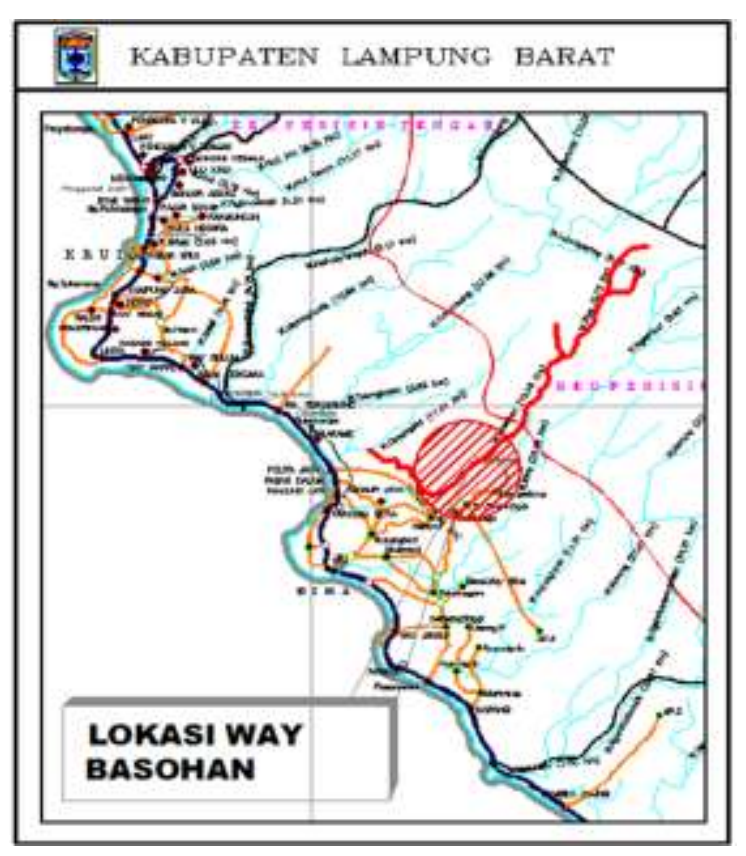

Gambar 4 Peta Lokasi Bendung Basohan 
Hasil perhitungan debit banjir rancangan metode rasional pada lokasi penelitian Tabel di bawah ini menunjukkan perhitungan debit banjir rancangan DAS Basohan dengan menggunakan metode Rasional Mononobe.

Tabel 4.7 Hasil Perhitungan Debit Banjir Rancangan Basohan dengan Metode Rasional Mononobe

\begin{tabular}{|c|c|c|c|c|c|c|c|}
\hline $\mathbf{n}$ & $\overline{\mathbf{R}}$ & $\bar{v}$ & $t$ & $\mathbf{r}$ & & $\overline{\mathbf{A}}$ & Qn \\
\hline $\begin{array}{l}\text { (Th } \\
\text { n) }\end{array}$ & (mm) & $\begin{array}{c}( \\
\mathbf{k m} / \mathbf{j a} \\
\mathbf{m})\end{array}$ & $\begin{array}{l}\text { (ja } \\
\mathbf{m})\end{array}$ & $\begin{array}{c}( \\
\mathbf{m m} / \mathbf{j a} \\
\mathbf{m})\end{array}$ & $\alpha$ & $\frac{(}{\mathbf{k m}^{2}}$ & $\begin{array}{c}( \\
\mathbf{m}^{3} / \mathrm{de} \\
\mathbf{t})\end{array}$ \\
\hline 2 & $\begin{array}{c}154.7 \\
788\end{array}$ & 1.8287 & $\begin{array}{c}3.42 \\
69\end{array}$ & $\begin{array}{c}18.885 \\
8\end{array}$ & $\begin{array}{c}0.75 \\
62\end{array}$ & 45 & $\begin{array}{c}178.5 \\
230\end{array}$ \\
\hline 5 & $\begin{array}{c}204.0 \\
539\end{array}$ & 1.8287 & $\begin{array}{c}3.42 \\
69\end{array}$ & $\begin{array}{c}24.898 \\
2\end{array}$ & $\begin{array}{c}0.75 \\
62\end{array}$ & 45 & $\begin{array}{c}235.3 \\
572\end{array}$ \\
\hline 10 & $\begin{array}{c}233.9 \\
908\end{array}$ & 1.8287 & $\begin{array}{c}3.42 \\
69\end{array}$ & $\begin{array}{c}28.551 \\
0\end{array}$ & $\begin{array}{c}0.75 \\
62\end{array}$ & 45 & $\begin{array}{c}269.8 \\
867\end{array}$ \\
\hline 25 & $\begin{array}{c}269.3 \\
320\end{array}$ & 1.8287 & $\begin{array}{c}3.42 \\
69\end{array}$ & $\begin{array}{c}32.863 \\
3\end{array}$ & $\begin{array}{c}0.75 \\
62\end{array}$ & 45 & $\begin{array}{c}310.6 \\
495\end{array}$ \\
\hline 50 & $\begin{array}{c}294.0 \\
970\end{array}$ & 1.8287 & $\begin{array}{c}3.42 \\
69\end{array}$ & $\begin{array}{c}35.885 \\
0\end{array}$ & $\begin{array}{c}0.75 \\
62\end{array}$ & 45 & $\begin{array}{c}333.1 \\
631\end{array}$ \\
\hline 100 & $\begin{array}{c}317.6 \\
198\end{array}$ & 1.8287 & $\begin{array}{c}3.42 \\
69\end{array}$ & $\begin{array}{c}38.755 \\
2\end{array}$ & $\begin{array}{c}0.75 \\
62\end{array}$ & 45 & $\begin{array}{c}366.3 \\
450\end{array}$ \\
\hline
\end{tabular}

Hasil perhitungan debit banjir rancangan dengan menggunakan metode Haspers disajikan di bawah ini.

Tabel 4.8 Hasil Perhitungan Debit Banjir Rancangan Basohan dengan Metode Haspers

\begin{tabular}{|c|c|c|c|c|c|c|c|c|}
\hline $\begin{array}{c}\mathrm{n} \\
\text { (Tahun) }\end{array}$ & $\begin{array}{c}\mathrm{R}_{\mathrm{n}} \\
(\mathrm{mm})\end{array}$ & $\begin{array}{c}\mathrm{t} \\
\text { (jam) }\end{array}$ & $\begin{array}{c}\mathrm{r} \\
(\mathrm{mm})\end{array}$ & $\alpha$ & $\beta$ & $\begin{array}{c}\mathrm{q}_{\mathrm{t}} \\
\left(\mathrm{m}^{3} / \mathrm{d} / \mathrm{km}^{2}\right)\end{array}$ & $\begin{array}{c}\mathrm{A} \\
\left(\mathrm{km}^{2}\right)\end{array}$ & $\begin{array}{c}Q_{\mathrm{n}} \\
\left(\mathrm{m}^{3} / \mathrm{dt}\right)\end{array}$ \\
\hline \hline 2 & 154.7788 & 3.4269 & 77.8799 & 0.7562 & 0.8375 & 6.3129 & 45 & 179.9138 \\
\hline 5 & 204.0539 & 3.4269 & 102.6736 & 0.7562 & 0.8375 & 8.3226 & 45 & 237.1908 \\
\hline 10 & 233.9908 & 3.4269 & 117.7369 & 0.7562 & 0.8375 & 9.5437 & 45 & 271.9892 \\
\hline 25 & 269.3320 & 3.4269 & 135.5195 & 0.7562 & 0.8375 & 10.9851 & 45 & 313.0696 \\
\hline 50 & 294.0970 & 3.4269 & 147.9804 & 0.7562 & 0.8375 & 11.9952 & 45 & 341.1652 \\
\hline 100 & 317.6198 & 3.4269 & 159.8164 & 0.7562 & 0.8375 & 12.9546 & 45 & 369.1990 \\
\hline
\end{tabular}

\begin{tabular}{|c|c|c|c|c|c|c|c|c|}
\hline Luas DPS & & A & $=$ & \multicolumn{2}{|c|}{$45.00 \mathrm{~km} 2$} & & & \\
\hline Panjang Sungai & & $\mathrm{L}$ & $=$ & \multicolumn{2}{|c|}{$27.40 \mathrm{~km}$} & & & \\
\hline Koefisien Pengall & & c & $=$ & \multicolumn{2}{|c|}{0.756} & & & \\
\hline Tenggang Waktt & \multicolumn{3}{|c|}{$=\mathrm{Tg} 1=0.21 * \mathrm{~L}^{\wedge} 0.70$} & \multicolumn{2}{|c|}{ UntukL<15 KM } & $=$ & 2.131 & Jam \\
\hline \multicolumn{4}{|c|}{ Tenggang Waktu $=\operatorname{Tg} 2=0.400 .058 * \mathrm{~L}$} & \multicolumn{2}{|c|}{ UntukL $>15 \mathrm{KM}$} & $=$ & 1.989 & Jam \\
\hline \multicolumn{4}{|c|}{ Tenggang Waktu $=\mathrm{Tg}=$} & & & $=$ & 1.989 & Jam \\
\hline \multicolumn{4}{|c|}{ Satuan Waktu Hidro. $=\operatorname{Tr} \quad=0,75^{*} \mathrm{Tg}$} & & & $=$ & 1.492 & Jam \\
\hline \multicolumn{4}{|c|}{ Waktu awal s/d banjir $=\mathrm{Tp}=\mathrm{Tg}+0 . .^{*} \mathrm{Tr}$} & & & $=$ & 3.183 & Jam \\
\hline \multicolumn{4}{|c|}{ Parameter Hidrograf $=a=\left(1 / \mathrm{gg} * 0.47 * \mathrm{~A}^{*} \mathrm{~A} \mathrm{~L}^{\wedge}\right)^{0.25}$} & & & $=$ & 1.400 & \\
\hline \multicolumn{4}{|c|}{ Waktu turun $30 \% \mathrm{Qp}=\mathrm{T} 0.3=\mathrm{a}$ Tg } & & & $=$ & 2.785 & Jam \\
\hline \multicolumn{4}{|c|}{ Waktu turun $\quad$ Qpd.1 $1=T p+T 0,3$} & & & $=$ & 5.968 & Jam \\
\hline \multicolumn{4}{|c|}{ Waktu turun $\quad$ Qpd.2 $=T p+1,5 * 0,3$} & & & $=$ & 7.360 & Jam \\
\hline \multicolumn{4}{|c|}{ Waktu turn $\quad$ Qpd. $3=T \mathrm{p}+2,5 * \mathrm{*} \times 0,3$} & & & $=$ & 10.145 & Jam \\
\hline \multicolumn{4}{|c|}{ Debit Puncak $\quad=Q p=(C . A . R o) /(3.6 * 0.3 T p+T 0.3)$} & & & $=$ & 2.528 & m3/det/nm \\
\hline Kurva Naik & \multicolumn{3}{|c|}{$=Q t=Q p\left(t / T p p^{\mu} 24\right.$} & & \multicolumn{4}{|c|}{ Untuk $0<\mathrm{t}<\mathrm{Tp}$} \\
\hline Kurva Turun & \multicolumn{3}{|c|}{$=Q t=Q p * 0.3^{\wedge}(t-T p / 70.3)$} & & \multicolumn{4}{|c|}{ Untuk $\operatorname{Tp}<t<(T p+T 0,3)$} \\
\hline Kurva Turnn & \multicolumn{4}{|c|}{ 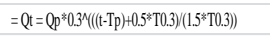 } & \multicolumn{4}{|c|}{ Untuk $(\mathrm{Tp}+\mathrm{T} 0.3)<\mathrm{t}<(\mathrm{Tp}+1.5 \mathrm{~T} 0.3)$} \\
\hline Kurva Turun & \multicolumn{4}{|c|}{ 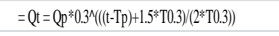 } & \multicolumn{4}{|c|}{ Untukt $>(T p+2.5 T 0.3)$} \\
\hline
\end{tabular}

Tabel 4.9 Hasil Perhitungan Debit Banjir Rancangan Km. 105+392 dengan Metode HSS Nakayasu

\begin{tabular}{|l|c|c|c|c|c|c|}
\hline Kala Ulang & t(jam) & U(t,1) & tl & t2 & t3 & Otot \\
\hline 5Tahun & 3.183 & 2.528 & 122.018 & 27.519 & 10.400 & 159.937 \\
\hline 10Tahun & 3.183 & 2.528 & 162.676 & 36.689 & 9.726 & 209.092 \\
\hline 25 Tahun & 3.183 & 2.528 & 244.887 & 55.231 & 14.641 & 314.759 \\
\hline 50Tahun & 3.183 & 2.528 & 244.887 & 55.231 & 14.641 & 314.759 \\
\hline 100Tahun & 3.183 & 2.528 & 277.433 & 62.571 & 16.587 & 356.591 \\
\hline
\end{tabular}

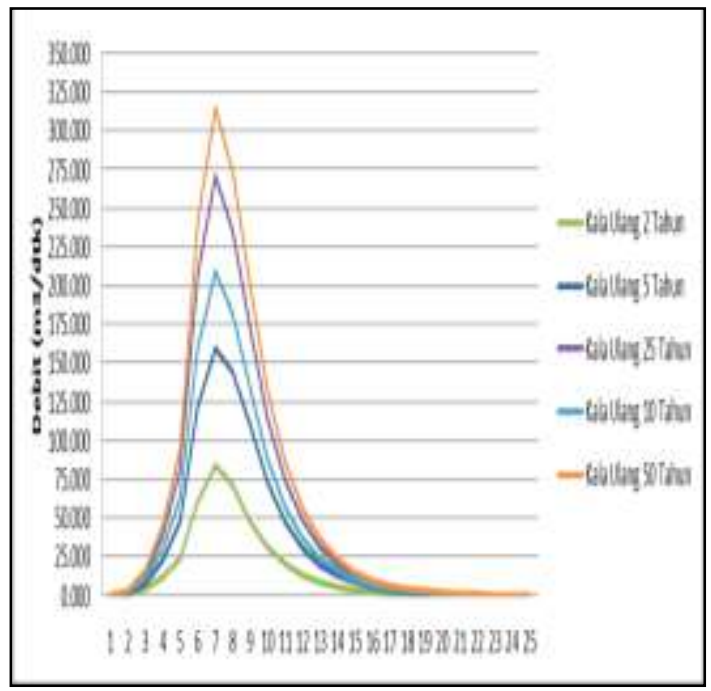

Gambar 5. Hidrograf Satuan Sintetik Metode Nakayasu Sungai Basohan 


\section{Metode HSS Snyder}

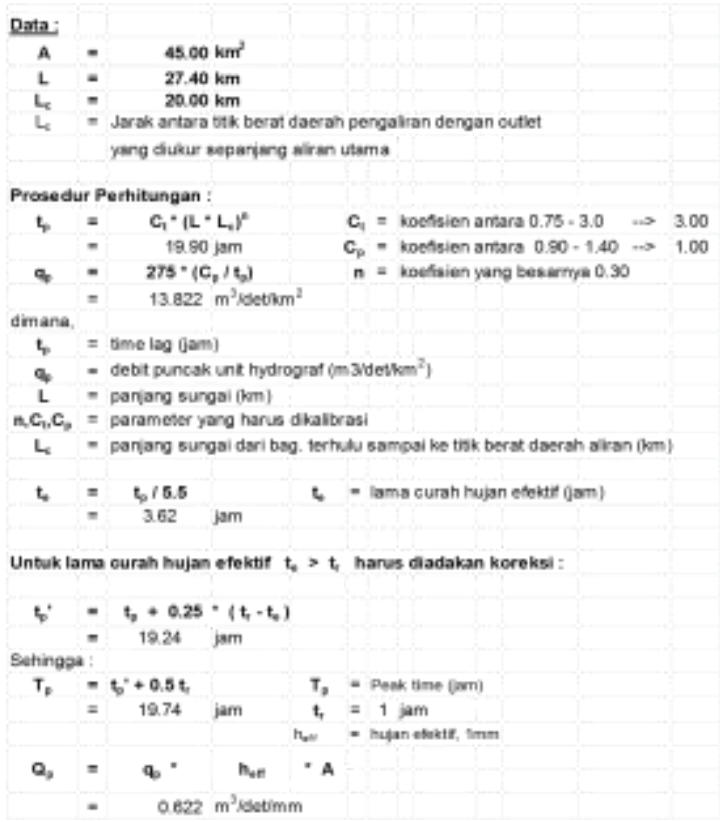

Tabel 10. Hasil Perhitungan Debit Banjir Rancangan Sungai Basohan dengan Metode HSS Snyder

\begin{tabular}{|c|c|c|c|c|c|}
\hline \multirow{2}{*}{ No. } & $\mathbf{t}$ & \multicolumn{3}{|c|}{} \\
\cline { 3 - 6 } & $\mathbf{j a m}$ & $\mathbf{T r}=\mathbf{5}$ Thn & $\mathbf{T r}=\mathbf{1 0} \mathbf{~ T h n}$ & $\mathbf{T r}=\mathbf{2 5} \mathbf{~ T h n}$ & $\mathbf{T r}=\mathbf{5 0}$ Thn \\
\hline 1 & 0 & 0.0000 & 0.0000 & 0.0000 & 0.0000 \\
\hline 3 & 2 & 3.4589 & 4.2239 & 4.7511 & 5.3672 \\
\hline 5 & 4 & 39.3766 & 47.9178 & 53.9980 & 61.0249 \\
\hline 10 & 8 & 157.6940 & 190.8824 & 215.7098 & 244.4674 \\
\hline 12 & 10 & 180.5154 & 218.1402 & 246.7327 & 280.2727 \\
\hline 16 & 14 & 206.5191 & 249.4336 & 282.2062 & 321.0642 \\
\hline 20 & 22 & 219.4653 & 265.0200 & 299.8705 & 341.2429 \\
\hline 23 & 25 & 217.7967 & 262.9416 & 297.5569 & 338.7814 \\
\hline 31 & 40 & 189.4189 & 228.6085 & 258.7479 & 294.7475 \\
\hline 37 & 54 & 157.2669 & 189.7663 & 214.8078 & 244.7711 \\
\hline 45 & 74 & 114.8852 & 138.6172 & 156.9145 & 178.8287 \\
\hline 55 & 136 & 37.7559 & 45.3061 & 51.4363 & 58.9159 \\
\hline \hline
\end{tabular}

\begin{tabular}{|l|l|l|l|l|}
\hline $\mathbf{Q}_{\text {MAKSIMUM }}$ & 219.4653 & 265.0200 & 299.8705 & 341.2429 \\
\hline
\end{tabular}

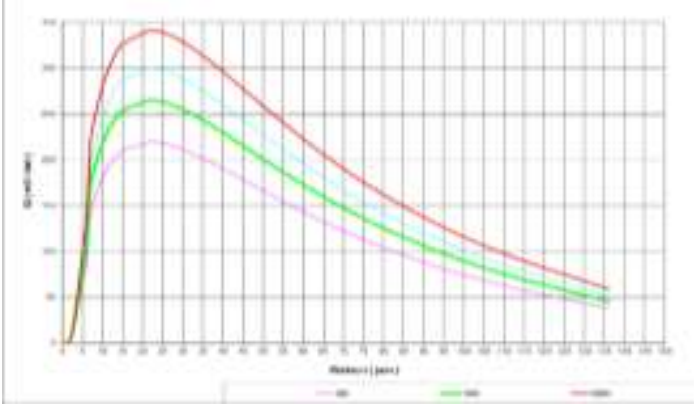

Gambar 6. Hidrograf Satuan Sintetik

Metode Snyder Debit Banjir

Rancangan untuk Sungai

Basohan
Perhitungan Rembesan

\begin{tabular}{|c|c|c|c|c|c|c|}
\hline \multirow{2}{*}{$\begin{array}{l}\text { Titik } \\
\text { Point }\end{array}$} & \multirow{2}{*}{$\begin{array}{c}\text { Garis } \\
\text { Line }\end{array}$} & \multicolumn{4}{|c|}{ Panjang Rembesan } & \multirow{2}{*}{$\begin{array}{c}\Delta \mathrm{H}= \\
\mathbf{L w} / \mathbf{C} \\
\mathbf{w}\end{array}$} \\
\hline & & Ver & Hor & $\begin{array}{c}1 / 3 \\
\text { Hor }\end{array}$ & Lw & \\
\hline & & (m) & (m) & (m) & (m) & $\begin{array}{c}(\mathbf{k N} / \mathbf{m} \\
2)\end{array}$ \\
\hline \multirow[t]{2}{*}{$\mathrm{A} 0$} & & & & & 0,00 & 0,00 \\
\hline & $\mathrm{A} 0-\mathrm{A} 1$ & 2,00 & 0,00 & 0,00 & & \\
\hline \multirow[t]{2}{*}{$\mathrm{A} 1$} & & & & & 2,00 & 0,29 \\
\hline & $\mathrm{A} 1-\mathrm{A} 2$ & 0,00 & 0,29 & 0,10 & & \\
\hline \multirow[t]{2}{*}{$\mathrm{A} 2$} & & & & & 2,10 & 0,30 \\
\hline & A2-A3 & 3,00 & 0,00 & 0,00 & & \\
\hline \multirow[t]{2}{*}{$\mathrm{A} 3$} & & & & & 5,10 & 0,73 \\
\hline & A3-A4 & 0,00 & 0,22 & 0,07 & & \\
\hline \multirow[t]{2}{*}{$\mathrm{A} 4$} & & & & & 5,17 & 0,74 \\
\hline & A4-A5 & 3,00 & 0,00 & 0,00 & & \\
\hline \multirow[t]{2}{*}{ A5 } & & & & & 8,17 & 1,17 \\
\hline & A5-A6 & 0,00 & 0,29 & 0,10 & & \\
\hline \multirow[t]{2}{*}{ A6 } & & & & & 8,27 & 1,18 \\
\hline & A6-A7 & 1,75 & 0,40 & 0,13 & & \\
\hline \multirow[t]{2}{*}{ A7 } & & & & & 10,15 & 1,45 \\
\hline & A7-A8 & 0,00 & 2,50 & 0,83 & & \\
\hline \multirow[t]{2}{*}{$\mathrm{A} 8$} & & & & & 10,98 & 1,57 \\
\hline & A8-A9 & 0,50 & 0,00 & 0,00 & & \\
\hline \multirow[t]{2}{*}{ A99 } & & & & & 11,48 & 1,64 \\
\hline & A9-A10 & 0,00 & 0,50 & 0,17 & & \\
\hline \multirow[t]{2}{*}{$\mathrm{A} 10$} & & & & & 11,65 & 1,67 \\
\hline & A10-A11 & 0,25 & 0,00 & 0,00 & & \\
\hline \multirow[t]{2}{*}{ A11 } & & & & & 11,90 & 1,70 \\
\hline & A11-A & 0,00 & 2,40 & 0,80 & & \\
\hline \multirow[t]{2}{*}{$\mathrm{A}$} & & & & & 12,70 & 1,82 \\
\hline & A-B & 1,50 & 0,00 & 0,00 & & \\
\hline \multirow[t]{2}{*}{$\mathrm{B}$} & & & & & 14,20 & 2,03 \\
\hline & B-C & 0,00 & 0,14 & 0,05 & & \\
\hline \multirow[t]{2}{*}{$\mathrm{C}$} & & & & & 14,25 & 2,04 \\
\hline & C-D & 2,75 & 0,00 & 0,00 & & \\
\hline $\mathrm{D}$ & & & & & 17,00 & 2,43 \\
\hline & D-E & 0,00 & 0,22 & 0,07 & & \\
\hline E & & & & & 17,07 & 2,44 \\
\hline & E-F & 2,75 & 0,00 & 0,00 & & \\
\hline $\mathrm{F}$ & & & & & 19,82 & 2,84 \\
\hline & F-G & 0,00 & 4,64 & 1,55 & & \\
\hline G & & & & & 21,37 & 3,06 \\
\hline & G-H & 0,50 & 0,50 & 0,17 & & \\
\hline $\mathrm{H}$ & & & & & 22,03 & 3,15 \\
\hline & H-I & 0,00 & 1,00 & 0,33 & & \\
\hline I & & & & & 22,37 & 3,20 \\
\hline & I-J & 0,75 & 0,00 & 0,00 & & \\
\hline $\mathrm{J}$ & & & & & 23,12 & 3,31 \\
\hline & $\mathrm{J}-\mathrm{K}$ & 0,45 & 6,00 & 2,00 & & \\
\hline $\mathrm{K}$ & & & & & 25,57 & 3,66 \\
\hline & K-L & 1,20 & 0,50 & 0,17 & & \\
\hline $\mathrm{L}$ & & & & & 26,93 & 3,85 \\
\hline & L-M & 0,00 & 1,00 & 0,33 & & \\
\hline $\mathrm{M}$ & & & & & 27,27 & 3,90 \\
\hline & M-N & 2,20 & 0,00 & 0,00 & & \\
\hline $\mathrm{N}$ & & & & & 29,47 & 4,22 \\
\hline
\end{tabular}

$\mathrm{C}=3,00$ (kerikil kasar termasuk berangkal)

$\Delta \mathrm{h}=2,10 \mathrm{~m}$

$\mathrm{Lw}=29,47 \mathrm{~m}$

$\mathrm{Hw}=$ El. muka air hulu - El. ambang kolam

olak

$=91,1542-86,937$

$=4,2172 \mathrm{~m}$

$\mathrm{Cw}=\mathrm{Lw} / \mathrm{Hw}$

$=6,98732>\mathrm{C}(\mathrm{aman})$

$\mathrm{Lw}>\mathrm{C} . \Delta \mathrm{h}$

$29,47>6,3$ (ok) 


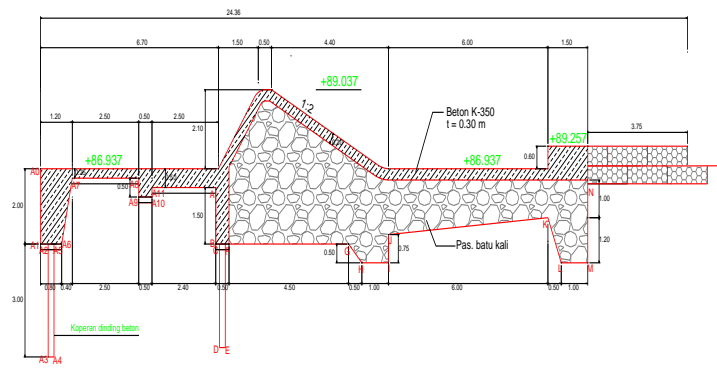

Gambar 7 Perhitungan Rembesan Metode

Lane pada Bendung Basohan

\section{Perhitungan Lantai Olak}

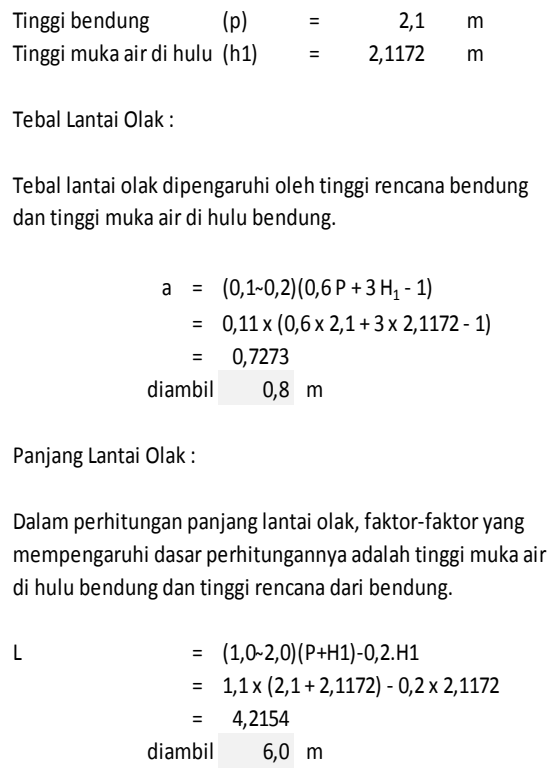

\section{KESIMPULAN DAN SARAN}

\section{Kesimpulan}

Berdasarkan hasil perhitungan dan analisis data diperoleh kesimpulan sebagai berikut.

1. Kerusakan bendungan di lokasi penelitian diakibatkan banjir dan seepage,

2. Hasil perhitungan curah hujan maksimum rancangan kala ulang 50 tahunan untuk stasiun Basohan adalah $294,097 \mathrm{~mm}$
3. Hasil perhitungan debit maksismum banjir rancangan dengan berbagai metode adalah sebesar $341,243 \mathrm{~m}^{3} / \mathrm{dtk}$ dengan metode HSS Snyder.

4. Berdasarkan data debit rancangan yang ada diperoleh ketinggian mercu yang dibutuhkan yaitu tipe bulat dengan elevasi 91,3076m di hulu dan 90,2958m di hilir bending.

5. Hasil perhitungan panjang coveran untuk mengurangi energi rembesan yaitu sepanjang $3 \mathrm{~m}$

6. Hasil perhitungan rembesan di dasar tubuh bendung diperoleh sepanjang 29,47 m. Dengan demikian panjang konstruksi dasar bendungan minimal harus sepanjang $29,47 \mathrm{~m}$.

7. Untuk meredam aliran pada saat keluar, maka didesain kolam olakan sepanjang $6 \mathrm{~m}$ dengan tebal lantai olak sebesar $0,8 \mathrm{~m}$. 